IZA DP No. 377

\title{
Intergenerational Progress of Mexican-Origin
} Workers in the U.S. Labor Market

\author{
Stephen J . Trejo
}

October 2001 


\title{
Intergenerational Progress of Mexican-Origin Workers in the U.S. Labor Market
}

\author{
Stephen J. Trejo \\ Department of Economics, University of Texas \\ and IZA, Bonn
}

\author{
Discussion Paper No. 377 \\ October 2001
}

\author{
IZA \\ P.O. Box 7240 \\ D-53072 Bonn \\ Germany \\ Tel.: +49-228-3894-0 \\ Fax: +49-228-3894-210 \\ Email: iza@iza.org
}

This Discussion Paper is issued within the framework of IZA's research area Mobility and Flexibility of Labor Markets. Any opinions expressed here are those of the author(s) and not those of the institute. Research disseminated by IZA may include views on policy, but the institute itself takes no institutional policy positions.

The Institute for the Study of Labor (IZA) in Bonn is a local and virtual international research center and a place of communication between science, politics and business. IZA is an independent, nonprofit limited liability company (Gesellschaft mit beschränkter Haftung) supported by the Deutsche Post AG. The center is associated with the University of Bonn and offers a stimulating research environment through its research networks, research support, and visitors and doctoral programs. IZA engages in (i) original and internationally competitive research in all fields of labor economics, (ii) development of policy concepts, and (iii) dissemination of research results and concepts to the interested public. The current research program deals with (1) mobility and flexibility of labor markets, (2) internationalization of labor markets and European integration, (3) the welfare state and labor markets, (4) labor markets in transition, (5) the future of work, (6) project evaluation and (7) general labor economics.

IZA Discussion Papers often represent preliminary work and are circulated to encourage discussion. Citation of such a paper should account for its provisional character. 
IZA Discussion Paper No. 377

October 2001

\section{ABSTRACT}

\section{Intergenerational Progress of Mexican-Origin Workers in the U.S. Labor Market}

Using unique Current Population Survey data from November 1979 and 1989, this paper compares the wage structure across generations of Mexican-origin men. I find that the sizable earnings advantage U.S.-born Mexican Americans enjoy over Mexican immigrants arises not just from intergenerational improvements in years of schooling and English proficiency, but also from increased returns to human capital for Mexican-origin workers who were born and educated in the United States. Even if we consider immigrants who have worked in the United States for 40 years and who therefore have had ample time for labor market assimilation, my estimates indicate that a discrete jump in earnings and the wage structure occurs between the first and second generations. Progress seems to stall after the second generation, however, as the much more modest gains in schooling and English fluency that occur between the second and third generations do not appear to raise the earnings of Mexican Americans any further.

JEL Classification: J15, J61, J31

Keywords: Mexican, wages, intergenerational

Steve Trejo

Department of Economics

University of Texas

Austin, TX 78712-1173

USA

Tel.: +1 512 475-8512

Fax: +1512 4713510

Email: trejo@eco.utexas.edu 


\section{Introduction}

Because of the large volume of U.S. immigration from Mexico over the past several decades, most Mexican-origin workers in the United States come from families that have been in this country for no more than two generations. In the national samples of men analyzed below, for example, roughly two-thirds of Mexican ethnics are either immigrants or the sons of immigrants. By way of comparison, only about 10 percent of non-Hispanic whites fit the same description. Mindful of this demographic reality, I study here intergenerational changes in the labor market opportunities of Mexican-origin workers and the implications for the long-term economic prospects of Mexican Americans.

Some analysts believe that this high concentration of relatively recent arrivals is the primary reason for the low average earnings of Mexican-origin workers. From the perspective of Chavez (1991), the descendants of Mexican immigrants are enjoying the same kind of intergenerational progress that allowed previous groups of unskilled immigrants, such as the Italians and Irish, to eventually enter the economic mainstream of American society. In contrast, Chapa (1990) sees little evidence that Mexican Americans are making steady progress toward economic parity with Anglos, and he worries about the emergence of a Chicano underclass with many of the same problems faced by inner-city blacks.

In a recent paper (Trejo 1997), I find some empirical support for each side of this debate. On the one hand, dramatic intergenerational improvements in human capital and earnings occur between Mexican immigrants and their U.S.-born children, as emphasized by Chavez (1991). Moreover, given their skills, Mexican-American workers enjoy labor market opportunities similar to those of non-Hispanic whites. On the other hand, intergenerational 
progress stalls after the second generation, leaving third- and higher-generation Mexicans trailing the education and earnings of the average American to an extent that justifiably concerns Chapa (1990).

To gain a better understanding of these issues, the current paper analyzes the labor market progress of Mexican-origin men across generations, using data from the Current Population Survey that is uniquely well-suited for this task. How do the wages and human capital of Mexican workers in the United States compare across generations? What roles do intergenerational changes in human capital and the wage structure play in determining intergenerational differences in earnings? How much of the substantial wage growth for Mexicans that takes place between the first and second generations actually occurs within the first generation as Mexican immigrants assimilate in the U.S. labor market? How do the intergenerational patterns for Mexicans compare with those for non-Hispanic whites? These are some of the questions I hope to shed light on.

I find that the sizable earnings advantage U.S.-born Mexican Americans enjoy over Mexican immigrants arises not just from intergenerational improvements in years of schooling and English proficiency, but also from increased returns to human capital for Mexican-origin workers who were born and educated in the United States. Even if we consider immigrants who have worked in the United States for 40 years and who therefore have had ample time for labor market assimilation, my estimates indicate that a discrete jump in earnings and the wage structure occurs between the first and second generations. The current analysis of Mexican intergenerational progress distinguishes itself from previous work (Chapa 1990; Chavez 1991; Allensworth 1997; Trejo 1997) by providing a more detailed and comprehensive investigation 
of how the wage structure evolves and also by differentiating the effects of immigrant labor market assimilation from changes across generations.

\section{Data and Basic Patterns}

I analyze microdata from the November 1979 and November 1989 Current Population Survey (CPS). In addition to the demographic and labor force information routinely collected in the CPS, these months included supplemental questions about country of birth for the respondent and his parents, and about the respondent's ability to speak English. As a result, these surveys provide the best recent data for studying the intergenerational progress of Mexican-origin workers in the U.S. labor market. ${ }^{1}$

I restrict the analysis to male wage and salary workers aged 18-61. Women are excluded to minimize biases arising from selective labor force participation, and the selfemployed cannot be studied because the basic monthly CPS collects no data on their income. Using the information on race and Spanish origin, I identify the two racial/ethnic groups that are included in my study: Mexicans and non-Hispanic whites. Other race and Spanish origin groups are excluded because CPS sample sizes are too small to permit the kind of intergenerational analysis reported below.

From the information on the nativity of each person and his parents, I define three generation categories. The first generation consists of immigrants: foreign-born individuals whose parents were also born outside of the United States. The second generation denotes U.S.-born individuals who have at least one foreign-born parent. The third generation identifies 
U.S. natives whose parents are also natives. Therefore, strictly speaking, the group I will refer to as the third generation actually includes the third and all higher-order generations. For Mexican Americans, this group consists primarily of individuals who are indeed third generation, whereas among non-Hispanic whites most people I refer to as third generation actually belong to higher generations (Borjas 1994, Tables 1 and 2). This discrepancy is unlikely to affect my comparisons between Mexicans and whites, however, because the intergenerational progress of European ethnic groups in the United States is largely complete by the second or third generation (Chiswick 1977; Neidert and Farley 1985; Perlmann and Waldinger 1997).

I exclude from analysis foreign-born individuals who have at least one U.S.-born parent, as well as those who do not report year of arrival in the United States. Also excluded are individuals for whom generation cannot be determined because birthplace data are missing for themselves or either parent. Finally, in order to avoid complications that arise with immigrants who arrived as children, I exclude all foreign-born individuals whose age and arrival cohort imply any possibility that they entered the United States prior to age $16 .^{2}$

Each month, the CPS collects earnings data only for the quarter of the respondents who are in outgoing rotation groups. For the remainder of the sample, I merged earnings information from the CPS outgoing rotation group files with the November CPS data. In this way, I

\footnotetext{
${ }^{1}$ The 1980 and later Censuses dropped the questions about parents' birthplace that were included in earlier Censuses. Starting in January 1994, the CPS now elicits the nativity of each individual and his parents, but information on English language proficiency is not routinely collected.

${ }^{2}$ Immigrants who arrive as children, and who therefore acquire much of their education and all of their work experience in the United States and who are more likely to speak English fluently, enjoy greater economic success than immigrants who come as adults (Kossoudji 1989; Friedberg 1991; Smith 1991; Allensworth 1997). Given the age and other restrictions typically used to construct analysis samples, the average age at arrival within the extracted subsample of a cohort falls with duration of residence in the United States, because as an immigrant arrival cohort ages, its youngest members enter the sample and its oldest members leave the sample. These factors combine to produce a spurious correlation between immigrant outcomes and duration of U.S. residence.
} 
obtained earnings data for about 90 percent of the workers for whom such data are unavailable in the November surveys. ${ }^{3}$

The data on usual weekly earnings are topcoded at \$999 in the 1979 CPS and $\$ 1,923$ in the 1989 CPS. According to the GNP deflator for personal consumption expenditure, the price level rose by 63 percent between November 1979 and November 1989. Therefore, in order to impose the same topcode (in real dollars) across years, I lower the weekly earnings ceiling in the 1989 data to $\$ 1,625$ (\$999 inflated from 1979 to 1989 dollars). Hourly earnings are then computed as the ratio of usual weekly earnings to usual weekly hours of work. For 1979 , workers with computed hourly wages below $\$ 1$ or above $\$ 100$ are considered outliers and excluded. For 1989 , corresponding wage thresholds of $\$ 1.63$ and $\$ 163$ are applied so as to be consistent in real terms. It turns out that few observations are affected by earnings topcoding or the deletion of wage outliers, and it matters little for the results whether I include or exclude these workers.

Table 1 reports summary statistics, by ethnicity and generation, for the key variables in my analysis. Sample means from the 1979 data occupy the top panel of the table and the 1989 means are presented in the bottom panel, with standard errors of the means shown in parentheses. The CPS sampling weights were used in these calculations.

To facilitate comparisons across years, the 1979 wage data reported in Table 1 were transformed into 1989 dollars using the GNP deflator. Education represents completed years

\footnotetext{
${ }^{3}$ The merged earnings data come from the three months immediately following the November surveys. The match keys used to merge these data are rotation group, household identification number, person identification number (or line number), household number (which indicates whether the household occupying a residential unit has changed), sex, race, and age. Because a birthday can take place between survey months, age is allowed to increase by up to one
} 
of schooling. In calculating potential labor market experience, years before age 14 are not counted (i.e., experience is defined as $E X P=A G E-\max [E D+6,14]$, where $A G E$ is current age and $E D$ is years of schooling). The November CPS questions on English proficiency are the same as those in the 1980 and 1990 Censuses. All respondents were asked whether they "speak a language other than English at home," and only those who answered affirmatively were asked how well they speak English, with possible responses of "very well," "well," "not well," or "not at all." For the tabulations reported in Table 1, English monolinguals are presumed to speak English "very well" and are grouped together with bilinguals who indicated the highest level of English proficiency. Finally, for immigrants, I construct a variable measuring years of U.S. residence by assigning midpoints of the arrival year intervals reported in the CPS. ${ }^{4}$

Overall, Mexican-origin men earn much lower wages on average than white men, and this wage deficit grew from 24 percent in 1979 to over 32 percent in 1989. ${ }^{5}$ Although some of the gap is explained by the large proportion of very low-paid immigrants among Mexicans, even U.S.-born Mexican Americans are at a substantial wage disadvantage. In 1989, for example, second-generation Mexicans earned 34 percent less than second-generation whites, and the corresponding wage gap among third-generation men was 24 percent. Previous research consistently shows that most of the wage deficit suffered by Mexican-origin workers can be

year without invalidating a match. The CPS samples housing units rather than individuals or families, so nonmatches typically occur when people change residences between survey dates.

${ }^{4}$ For immigrants arriving in the open-ended intervals ("before 1950" in the 1979 CPS and "before 1960" in the 1989 CPS), I set years of U.S. residence equal to 35.

${ }^{5}$ For expositional convenience, throughout the paper I will treat log wage differences as representing percentage wage differentials, although I recognize that this approximation becomes increasingly inaccurate for log differences on the order of .25 or more in absolute value. In such instances, one can calculate the implied percentage wage differential as $e^{x}-1$, where $x$ represents the difference in mean log wages between the relevant groups. 
attributed to low levels of human capital (Gwartney and Long 1978; Reimers 1983; Carlson and Swartz 1988; Carnoy, Daley, and Hinojosa-Ojeda 1993; Trejo 1997), a finding that is not surprising in light of the skill measures presented in Table 1. Mexicans possess much less schooling than whites, are younger, and are more likely to report English language deficiencies. The human capital deficit is most severe for Mexican immigrants, but it remains large even among U.S.-born workers.

Intergenerational comparisons yield different patterns for Mexicans and whites. For whites, earnings do not rise systematic ally across generations; in fact, average wages are actually lowest for the third generation, but this mainly reflects the relative youth of these workers (Trejo 1996). Conversely, Mexican-origin workers display substantial wage growth of about 30 percent between the first and second generations, a phenomenon that is undoubtedly related to the dramatic intergenerational improvements in educational attainment and English proficiency that take place. Progress appears to stall at this point, with the much more modest gains in schooling and English fluency that occur between the second and third generations unable to raise the average earnings of Mexican Americans any further (although, as with whites, the relative youth of third-generation workers confounds comparisons across generations). Finally, note that linguistic assimilation is completed sooner for whites than for Mexicans. By the second generation, virtually all whites are fluent in English, whereas a surprisingly large fraction (16 percent in 1979 and 9 percent in 1989) of third-generation Mexicans speak English less than "very well." 


\section{Econometric Framework}

In order to shed light on the questions about the intergenerational labor market progress of Mexican-origin men posed at the beginning of the paper, I undertake a systematic analysis of the November 1979 and 1989 CPS data described in the preceding section. Within the framework developed by Borjas $(1985,1995)$ for estimating the effects of arrival cohort and duration of U.S. residence on the earnings of immigrants, I compare wage structures across first-, second-, and third-generation Mexican and white men. This framework exploits the availability of comparable cross-section data from two different points in time.

To understand the essence of the empirical approach, think about estimating separate cross-section wage regressions for every ethnicity/generation group in each survey year. In other words, a wage regression is estimated for Mexican immigrants in the 1979 CPS data, another regression is estimated for Mexican immigrants in the 1989 CPS data, still another regression is estimated for second-generation Mexicans in the 1979 CPS data, and so on, with the twelfth and final regression in this sequence being for third-generation whites in the 1989 CPS data. For U.S.-born workers, these regressions can identify all wage equation parameters of interest, but not so for immigrants. Without strong restrictions, cross-section regressions cannot distinguish immigrant cohort and assimilation effects, because at any given point in time variation across immigrants in years of U.S. residence arises only from differences in year of entry to the United States.

With repeated cross-sections, however, outcomes for immigrant arrival cohorts can be tracked over time, and the trick then becomes to isolate changes due to assimilation from changes caused by different economic conditions in the survey years being compared (i.e., 
period effects). The most popular solution to this problem, and the one adopted here, is to estimate period effects from the outcome changes experienced by an appropriate group of native workers. After netting out these estimates of the period effects, remaining changes for immigrant cohorts are attributed to assimilation. A key assumption of this approach is that compositional changes in the subsample of an immigrant cohort observed in the U.S. labor market— such as those caused by emigration, mortality, and labor force entry and exit — do not bias measured outcome changes.

To be explicit, let $y_{i}^{e g}$ represent the hourly earnings of worker $i$ in ethnic group $e$ and generation $g$, where $e$ takes on the values $m$ for Mexican and $w$ for white, and $g$ takes on the values 1, 2, and 3 for first, second, and third generations, respectively. Pooling data from the 1979 and 1989 CPS, the log wage equation for Mexican immigrants is

$$
\begin{aligned}
\log \left(y_{i}^{m 1}\right)= & C_{i} \lambda^{m 1}+A_{i} \delta^{m 1}+\pi^{m} T_{i}+\left(1-T_{i}\right) X_{i} \beta_{79}^{m 1}+T_{i} X_{i} \beta_{89}^{m 1} \\
& +\left(1-T_{i}\right) L_{i} \theta_{79}^{m}+T_{i} L_{i} \theta_{89}^{m}+\left(1-T_{i}\right) Z_{i} \gamma_{79}+T_{i} Z_{i} \gamma_{89}+\varepsilon_{i}^{m 1}
\end{aligned}
$$

The vector $C$ is a set of dummy variables identifying immigrant arrival cohort, the vector $A$ contains years in the United States and its square, and $T$ is a dummy variable indicating observations from the 1989 survey. The vector $X$ contains potential labor market experience, its square, and, in the extended specification, completed years of schooling. The vector $L$ is a set of dummies indicating self-reported English language proficiency, and the vector $Z$ contains indicators for the month in which the earnings data were collected, metropolitan status, the nine Census divisions, and the states of California and Texas. ${ }^{6}$ Finally, $\varepsilon$ is a random error term,

\footnotetext{
${ }^{6}$ The earnings data were collected in either November, December, January, or February. The categories for metropolitan status are as follows: central city, elsewhere in a metropolitan statistical area (MSA), not in an MSA, and
} 
and the remaining parameters are the objects of estimation.

The analogous equations for second- and third-generation Mexicans are

$$
\begin{aligned}
\log \left(y_{i}^{m 2}\right)= & \alpha^{m 2}+\pi^{m} T_{i}+\left(1-T_{i}\right) X_{i} \beta_{79}^{m 2}+T_{i} X_{i} \beta_{89}^{m 2} \\
& +\left(1-T_{i}\right) L_{i} \theta_{79}^{m}+T_{i} L_{i} \theta_{89}^{m}+\left(1-T_{i}\right) Z_{i} \gamma_{79}+T_{i} Z_{i} \gamma_{89}+\varepsilon_{i}^{m 2}, \\
\log \left(y_{i}^{m 3}\right)= & \alpha^{m 3}+\pi^{m} T_{i}+\left(1-T_{i}\right) X_{i} \beta_{79}^{m 3}+T_{i} X_{i} \beta_{89}^{m 3} \\
& +\left(1-T_{i}\right) L_{i} \theta_{79}^{m}+T_{i} L_{i} \theta_{89}^{m}+\left(1-T_{i}\right) Z_{i} \gamma_{79}+T_{i} Z_{i} \gamma_{89}+\varepsilon_{i}^{m 3} .
\end{aligned}
$$

In equations (2) and (3), the $\alpha$ parameters represent generation-specific intercepts, and the arrival cohort and years in the United States variables are excluded because they are not relevant for U.S.-born workers.

To see the identification problem in equation (1), it is easiest to think of $C, A$, and $T$ as being scalar variables denoting, respectively, year of entry into the United States, years since entry, and survey year. In this case, $C+A=T$, which implies that we cannot estimate the separate effects of these variables without imposing some restriction. An analysis of immigrant earnings must confront the classic problem of identifying cohort, age, and period effects. The identifying restriction imposed in equations (1)-(3) is that the period effect $\pi^{m}$ is the same for all three generations of Mexican-origin workers. In essence, the period effect is estimated from U.S.-born workers, and this information is used to identify the cohort and assimilation effects for immigrants.

Equations (1)-(3) impose additional restrictions as well, but before discussing them, let

metropolitan status not identified. I include separate indicators for California and Texas because the Mexican-origin population is heavily concentrated in these two states. In my sample, over two-thirds of U.S.-born Mexicans and an even larger share of Mexican immigrants reside in either California or Texas. 
me write down the wage equations for whites, which are completely symmetric to tho se for Mexicans:

$$
\begin{aligned}
\log \left(y_{i}^{w 1}\right)= & C_{i} \lambda^{w 1}+A_{i} \delta^{w 1}+\pi^{w} T_{i}+\left(1-T_{i}\right) X_{i} \beta_{79}^{w 1}+T_{i} X_{i} \beta_{89}^{w 1} \\
& +\left(1-T_{i}\right) L_{i} \theta_{79}^{w}+T_{i} L_{i} \theta_{89}^{w}+\left(1-T_{i}\right) Z_{i} \gamma_{79}+T_{i} Z_{i} \gamma_{89}+\varepsilon_{i}^{w 1}, \\
\log \left(y_{i}^{w 2}\right)= & \alpha^{w 2}+\pi^{w} T_{i}+\left(1-T_{i}\right) X_{i} \beta_{79}^{w 2}+T_{i} X_{i} \beta_{89}^{w 2} \\
& +\left(1-T_{i}\right) L_{i} \theta_{79}^{w}+T_{i} L_{i} \theta_{89}^{w}+\left(1-T_{i}\right) Z_{i} \gamma_{79}+T_{i} Z_{i} \gamma_{89}+\varepsilon_{i}^{w 2}, \\
\log \left(y_{i}^{w 3}\right)= & \alpha^{w 3}+\pi^{w} T_{i}+\left(1-T_{i}\right) X_{i} \beta_{79}^{w 3}+T_{i} X_{i} \beta_{89}^{w 3} \\
& +\left(1-T_{i}\right) L_{i} \theta_{79}^{w}+T_{i} L_{i} \theta_{89}^{w}+\left(1-T_{i}\right) Z_{i} \gamma_{79}+T_{i} Z_{i} \gamma_{89}+\varepsilon_{i}^{w 3} .
\end{aligned}
$$

Recall the idea introduced earlier of estimating separate wage regressions for every ethnicity/generation group in each survey year. Such an approach is quite general in that it permits all parameters of the wage equation to vary across ethnicity, generation, and survey year; unfortunately, as discussed above, this approach does not provide identification of immigrant cohort and assimilation effects. To identify these effects, equations (1)-(6) assume that the cohort and assimilation parameters do not change over time, and also that the intercepts of the wage equations for first-, second-, and third-generation workers shift across survey years by the same amount.

Note, however, that immigrant cohort and assimilation effects and the period effect common to all generations are allowed to vary by ethnicity. Estimating these parameters separately for Mexicans and whites is important for at least two reasons. First, these immigrant groups differ tremendously in the kinds of skills they bring to the U.S. labor market (see Table 1), so it is not surprising that previous studies have found distinct cohort and assimilation 
patterns in the earnings of the two groups (Borjas 1995; Schoeni 1997). Second, the assumption of identical period effects for immigrant and native workers is more tenable within ethnic groups. Over the last two decades, overall earnings inequality and the labor market returns to education and other skill measures have increased in the United States (Murphy and Welch 1992; Juhn, Murphy, and Pierce 1993). If predominantly unskilled Mexican immigrants are compared to more skilled white workers, these changes in the wage structure depress the relative earnings growth of immigrants, possibly resulting in downward-biased estimates of assimilation and distorted estimates of cohort wage differences for Mexican immigrants (LaLonde and Topel 1992). In terms of educational attainment and labor market skills, Mexican immigrants are more similar to U.S.-born Mexicans than to whites of any generation (see Table 1), and therefore changes in the wage structure pose less of a problem when comparisons are made within rather than across ethnic groups.

Besides the immigrant cohort and assimilation effects and the generation-specific intercepts, all of the other parameters in equations (1)-(6) are allowed to differ between survey years, with the subscripts 79 and 89 indicating the year of a particular parameter vector. The additional restrictions imposed on the wage equations conserve degrees of freedom. I let the effects of English proficiency vary across ethnic groups and survey years, but not across generations, because the sample includes a fairly small number of U.S.-born workers who are not fluent in English. The coefficients of the survey month and geographic dummies differ over time but are constrained to be the same for all ethnicity/generation groups. One motivation for this restriction is that these variables are meant to capture temporal and regional variation in the cost-of-living and labor market conditions that may impact all groups to a similar extent. 
Moreover, the regional concentration of the Mexican-origin population and the relatively small Mexican samples in CPS data make it impossible to estimate separate coefficients for Mexicans with any precision.

To provide a brief summary of the foregoing discussion, Tabl 2 lists the restrictions imposed on the parameters of the wage equations. I estimate these parameters by ordinary least squares, pooling observations on workers from all ethnicity/generation groups in both survey years into a single log wage regression, and imposing the restrictions described in Table 2 by introducing appropriate interaction terms between ethnicity, generation, and survey year dummies and the other explanatory variables. The total sample size for this regression is 43,544 individuals, with the breakdown by ethnic group, generation, and survey year provided in Table 1. Two different regression specifications are estimated. What I refer to as the "base" specification includes all of the regressors listed in Table 2 except for education and the English proficiency dummies. The "extended" specification adds controls for education and English proficiency to the base specification.

Before turning to the estimation results, let me mention a couple of issues that may affect interpretation of the intergenerational earnings comparisons reported here. First, even though I use data from two different years (1979 and 1989) in order to estimate immigrant assimilation, my intergenerational comparisons are essentially cross-sectional because they do not attempt to match immigrant parents with their U.S.-born children who enter the labor market a couple of decades later. Instead, I compare first-, second-, and third-generation Mexicans during a single decade (the 1980s). An alternative approach would be to use data from successive time spans and compare immigrant adults in some initial period with their grown-up descendants twenty or 
more years later. Each approach has advantages and disadvantages. One benefit of the crosssectional approach is that using data from a single decade holds constant the social and economic environment, whereas the alternative approach can give misleading results when conditions change over time. For example, the civil rights movement may have generated economic gains for all generations of Mexicans over the 1970s and 1980s. If so, then the improvements in education and earnings observed between Mexican immigrants in the 1960s and their U.S.-born children in the 1990s would overstate the amount of progress that is solely due to being a second-generation Mexican who grew up in the United States rather than a firstgeneration Mexican who grew up south of the border.

On the other hand, Borjas (1993) cautions that cross-sectional comparisons across generations can be misleading if there are important skill differences between immigrant cohorts and these differences are at least partially transmitted to the U.S.-born children of immigrants. In particular, there is evidence that recent cohorts of Mexican immigrants came to the United States with fewer skills than preceding cohorts (Borjas 1995). Consequently, cross-sectional comparisons between first- and second-generation Mexicans may exaggerate the amount of intergenerational progress, because second-generation Mexicans currently in the labor market inherited their abilities and skills from earlier immigrant cohorts who were more successful than the immigrant cohorts now at work are likely to be. For the same reason, cross-sectional comparisons between second- and third-generation Mexican Americans may be biased in favor of the third generation, although this presumes that the skill decline observed for postwar cohorts of Mexican immigrants continues back well into the first half of this century. 
Selective return migration can produce similar biases. If, for example, unsuccessful immigrants have a greater tendency to return eventually to their home country, then as an immigrant arrival cohort ages in the United States, it becomes increasingly represented by more successful, higher-earning individuals. This process can generate inflated estimates of immigrant labor market assimilation and might also distort intergenerational comparisons, to the extent that the children of immigrants who remain here inherit some of their parents' selectivity. Available evidence on the selectivity of return migration is mixed, however. Overall, most research suggests that the least successful immigrants are most likely to leave the United States (Borjas 1989; Hu 1999; Lubotsky 2000), but Jasso and Rosenzweig (1988) find the opposite. Of greatest relevance for the current study, $\mathrm{Hu}$ (1999) reports that return migration selectivity is important for non-Hispanic immigrants but not for Hispanic immigrants, whereas according to Reyes (1997) it is the least educated and lowest paid immigrants from western Mexico who are most likely to return. To the extent that selective return migration does bias estimates of immigrant earnings functions, these studies suggest that rates of assimilation and immigrant wage growth are overestimated. Therefore, this type of bias cannot explain the findings reported below of meager wage growth for Mexican immigrants, relative to native whites, and of a large jump in earnings between long-term Mexican immigrants and second-generation Mexican Americans.

A final issue is that ethnic identification is to some extent endogenous, especially among people at least one or two generations removed from immigration to the United States (Waters 1990). Consequently, the descendants of Mexican immigrants who continue to identify themselves as Mexican-origin in the third and higher generations may be a select group. In 
particular, if the most successful Mexicans are more likely to intermarry or for other reasons cease to identify themselves or their children as Hispanic, then available data may understate human capital and earnings gains between the second and third generations. Though outside the scope of the current paper, an important question for future research is whether this phenomenon can explain why the economic progress of Mexican Americans appears to stall after the second generation.

\section{Estimation Results}

Tables 3 through 7 report the results from estimating equations (1)-(6) in the manner just described. These tables present selected coefficients and calculations from the two alternative regression specifications: the "base" specification, and the "extended" specification that also includes controls for education and English proficiency.

The coefficients of the education and experience variables are allowed to vary without restriction across ethnicity, generation, and survey year. Table 3 reports estimates of these coefficients from the extended specification that utilizes all of the regressors listed in Table 2, including the dummy variables indicating English language proficiency. To facilitate interpretation of the quadratic in experience, Table 3 also reports the implied cumulative returns to the first 10 and 20 years of labor market experience. Standard errors are provided in parentheses.

For every ethnicity/generation group, returns to schooling rose over the 1980s, a pattern consistent with the numerous U.S. studies documenting a steep climb during this decade in the earnings premium associated with formal education (e.g., Levy and Murnane 1992; Murphy and Welch 1992). 
For both Mexicans and whites, returns to education are higher for natives than immigrants, a well-known result typically thought to reflect the advantages of U.S. schooling for the U.S. labor market (Chiswick 1978). Borjas (1995) finds the same pattern in 1970-90 Census data. Unlike recent Census data, however, the November CPS data can distinguish second- and third-generation workers, and it is here that an interesting difference emerges between Mexicans and whites. In both 1979 and 1989, returns to education are essentially the same for second- and third-generation whites, whereas the Mexican returns rise for each successive generation, and not until the third generation do returns look similar for Mexicans and whites. For example, among Mexican-origin workers the 1989 returns to education grow from 2.6 percent for immigrants to 5.1 percent for the second generation and 7.7 percent for the third; the corresponding returns for whites are 5.7 percent for immigrants and 7.9 percent for the second and third generations. In their analysis of the November 1979 CPS data, Neidert and Farley (1985) report a similar pattern for Mexicans whereby the returns to education in terms of occupational status rise across generations.

The higher returns to education for white as compared to Mexican immigrants can be attributed to the superior quality of school systems in countries that white immigrants tend to hail from (Bratsberg and Terrell 1997), as well as the fact that many of these countries provide instruction in English. It is less obvious why whites should enjoy higher returns to education than Mexicans among second-generation workers who presumably attended U.S. schools, or why the percentage point improvement in the returns to education for Mexicans is at least as large between the second and third generations as between the first and second. One possible explanation is that, because some Mexican immigrants to the United States return to Mexico for 
extended periods (Massey et al. 1987; Reyes 1997), U.S.-born children of these immigrants may receive some of their education in Mexican schools. Moreover, the high concentration of Mexican immigrants in agriculture and other seasonal industries increases he chances that second-generation Mexican kids experience frequent moves that disrupt their schooling, even when these moves occur within the United States. ${ }^{7}$ Finally, the rural schools available to the U.S.-born children of Mexican immigrant farmworkers may be of lower quality than the urban and suburban schools attended by most third-generation Mexican schoolchildren.

In immigrant wage equations like those estimated here that include both potential experience and years of U.S. residence as explanatory variables, the experience coefficients measure the returns to labor market experience acquired by foreign-born workers before they moved to the United States (Chiswick 1978). ${ }^{8}$ Consequently, the lower returns to experience for first-generation men evident in Table 3 indicate that job training and work experience accumulated in the home country transfer imperfectly to the U.S. labor market. Among U.S.born workers, returns to experience are similar for all ethnicity/generation groups, which suggests that by the second generation Mexicans enjoy roughly the same wage growth as whites. By way of contrast, recall that returns to education take three generations to converge. Finally, returns to experience appear to have increased over the 1980s for all three generations

\footnotetext{
${ }^{7}$ Ream and Rumberger (1998) show that second-generation Mexicans change schools more frequently than do third- and higher-generation Mexicans, and they find that such mobility lowers the achievement test scores of secondgeneration Mexicans.

${ }^{8}$ To see this point, write experience as $E X P=A G E-E D-6$, where $A G E$ is current age and $E D$ is years of schooling. For immigrants, write years of U.S. residence as $Y U S=A G E-A R R$, where $A R R$ represents age upon arrival in the United States. In the wage regressions, the coefficients on experience capture the effect of increasing $E X P$ by one year while holding $E D$ and $Y U S$ fixed. Conceptually, this experiment raises $A G E$ and $A R R$ both by exactly one year, which in effect increases by one year the immigrant's experience in his home country labor market (assuming that the immigrant entered the labor force prior to moving to the United States).
} 
of Mexicans, whereas the corresponding returns declined for white immigrants and did not change much for U.S.-born whites.

Table 4 presents the estimated coefficients for the vector of dummy variables indicating English language proficiency, with English monolinguals-presumably the most proficient group - as the reference category. As with the education and experience coefficients just discussed, these coefficients are from the "extended" regression specification that includes all of the regressors listed in Table 2. For Mexicans, the language dummies show the expected pattern of more negative coefficients for dummies representing lower levels of proficiency in speaking English, and the same pattern holds for whites with the exception of the comparison between those who speak English "not well" and "not at all".

For immigrants, Table 5 reports the estimated coefficients of the quadratic in years of U.S. residence. These coefficients measure the additional return that the U.S. labor market pays immigrants for U.S. work experience compared to home country work experience. ${ }^{9}$ To quantify this immigrant wage growth arising from labor market assimilation, I present the implied cumulative returns to the first 10 and 20 years of U.S. residence. For foreign-born workers, total wage growth in the United States is the sum of the returns to years of U.S. residence and the returns to experience. ${ }^{10}$ The bottom rows of Table 5 report this total immigrant wage growth for the first 10 and 20 years in the United States. These calculations use 1989 estimates

\footnotetext{
${ }^{9}$ Referring back to the notation introduced in footnote 15 , the regression coefficients on years of U.S. residence measure the effect of increasing YUS by one year while holding EXP and $E D$ fixed. This is accomplished by keeping $A G E$ fixed and lowering $A R R$ by one year, which transforms a year of home country work experience into a year of U.S. work experience.

${ }^{10}$ Referring back once again to footnote 15, as a U.S. immigrant grows one year older, both EXP and YUS increase by one year each.
} 
of the returns to experience and assume that immigrants arrive in the United States at the beginning of their working lives. Separate estimates are presented for each of the two regression specifications described earlier.

Wage growth associated with assimilation is stronger for Mexicans than whites. Holding total (i.e., U.S. and foreign) work experience fixed, increasing U.S. work experience from 0 to 10 years raises immigrant earnings by 35 percent for Mexicans as compared to 22 percent for whites, according to the base specification that excludes education and the English proficiency dummies. In her analysis of 1980 and 1990 Census data for California and Texas, Reimers (1997) also reports higher returns to years of U.S. residence for Mexicans than for whites. One explanation for this finding is that because many white immigrants speak English and come from industrialized countries with economies similar to the United States, their work experience may transfer more easily to the U.S. labor market, and therefore the returns to U.S. work experience would not exceed the returns to home country work experience by as much for these immigrants. Conversely, differences in language and economic development between the United States and Mexico may create a situation where the U.S. labor market pays Mexican immigrants a substantial premium for U.S. work experience. This argument suggests that returns to pre-U.S. experience should be larger for white immigrants than for Mexican immigrants (Chiswick 1978; Duleep and Regets 1996). Looking back at the returns to experience for first-generation workers reported in Table 3, the expected pattern shows up in 1979 but not in 1989 .

Making comparisons across the columns of Table 5, for both Mexicans and whites the returns to U.S. residence become smaller after conditioning on education and, most importantly, 
English proficiency. For example, among Mexican immigrants, the returns to the first 10 years of U.S. residence fall from 35 percent in the base specification to 20 percent in the extended specification. For white immigrants, the corresponding decline in the returns to 10 years of U.S. residence is from 22 percent to 14 percent. The substantial drop in returns to U.S. residence when going from the base specification to the extended suggests that improvements in English language skills play an important role in the labor market assimilation of immigrants. Carliner (1996) and Funkhouser (1996) reach a similar conclusion in their analyses of 1980 and 1990 Census data.

By comparing the estimates of total immigrant wage growth reported in the bottom of Table 5 with the returns to experience for second- and third-generation workers presented in Table 3, we learn whether the earnings gap between Mexican immigrants and U.S.-born Mexican Americans narrows as immigrants spend more time in the United States. In the estimation framework employed here, labor market assimilation is measured by the extent to which the U.S. labor market rewards the U.S. work experience of immigrants more than it rewards their home country work experience, and so the presence of assimilation does not necessarily imply earnings convergence, because returns to experience can differ for immigrants and natives (LaLonde and Topel 1992).

These particular estimates show no evidence of life cycle earnings convergence between immigrant and native workers. For the regression specification that includes education and English proficiency and using 1989 estimates of the returns to experience, Table 5 indicates that the wages of Mexican immigrants grow 40 percent during their first 10 years and 59 percent during their first 20 years in the U.S. labor market. The corresponding estimates for second- 
generation Mexicans in Table 3 imply wage growth of 48 percent over 10 years and 73 percent over 20 years, so the large initial wage gap between first- and second-generation Mexicans actually widens during the first 20 years that immigrants work in the United States. Because returns to experience are similar for second- and third-generation Mexicans, the same lack of convergence emerges from earnings comparisons between the first and third generations. Among whites as well, U.S.-born workers enjoy greater wage growth than immigrants during the first 20 years of U.S. work experience, although the fact that white immigrants and natives resemble each other rather closely in terms of average earnings and education makes the issue of convergence somewhat less interesting for them.

For immigrants, Table 6 reports estimates of permanent wage differences across arrival cohorts, with the reference group for these comparisons being the cohort of immigrants of the same ethnicity who entered the United States before 1960. Because of the relatively small immigrant samples available in CPS data, I define cohorts more broadly (pre-1960, 1960-69, 1970-79, and 1980-89) than the five-year arrival intervals typically used with Census data. Statistical tests do not reject this aggregation of arrival cohorts, but these tests are not particularly powerful because the cohort effects are estimated imprecisely. The large standard errors indicate that CPS data are far from ideal for analyzing immigrant cohort effects. As a result, for neither Mexicans nor whites can I reject the hypothesis of no wage differences across immigrant cohorts, despite point estimates which suggest wage gaps of 30 percent or more between Mexican immigrants arriving before 1960 and those arriving afterward.

Table 7 and Figure 1 return to the question of how much progress Mexican immigrants make during their lifetimes in reducing their wage deficit relative to U.S.-born Mexican 
Americans. For each ethnicity/generation group and for both regression specifications, Table 7 presents predicted log wage differentials (relative to third-generation whites) at three points in the life cycle: ages 20,40, and 60. These calculations use estimated coefficients for 1989 and refer to an individual who entered the labor market at age 18. If an immigrant, the individual is assumed to have arrived in the United States at age 20 as part of the 1980-89 cohort. In the extended specification that controls for education and English proficiency, the individual is also assumed to speak only English and have 12 years of schooling. To further illustrate these patterns, Figure 1 displays the corresponding log wage profiles for Mexicans of each generation and for third-generation whites. ${ }^{11}$

Using estimated coefficients from the base specification, Mexican immigrants are predicted to earn 55 percent lower wages than third-generation whites at age 20, 59 percent lower wages at age 40, and 53 percent lower wages at age 60. For second-generation Mexicans, the corresponding wage deficits relative to third-generation whites are 25 percent at age 20, 20 percent at age 40, and 41 percent at age 60. Therefore, upon arrival in the United States at age 20, Mexican immigrants are predicted to earn 30 percent less than secondgeneration Mexicans, with this wage gap widening to 39 percent at age 40 before shrinking to 12 percent at age 60. Analogous comparisons between first- and third-generation Mexicans produce an immigrant wage disadvantage of 31 percent at age 20, 33 percent at age 40, and 42 percent at age 60. These calculations indicate that, over their working lives, Mexican

\footnotetext{
${ }^{11}$ Note that Table 7 reports predicted log wage differentials, relative to third-generation whites, whereas Figure 1 graphs predicted log wages. In addition to the assumptions made for the calculations in Table 7, the predicted wages shown in Figure 1 pertain to an individual who resides in a California central city and whose earnings we observe in the November survey month. Because of the restrictions imposed on the wage regressions, these additional
} 
immigrants do not narrow their wage deficits relative to third-generation Mexican Americans or whites, a result that is consistent with previous studies documenting weak U.S. wage growth for immigrants from Mexico (Smith 1991; Borjas 1995; Schoeni 1997). There is some evidence of wage convergence between first- and second-generation Mexicans during the latter half of their careers, but this occurs primarily because of slow wage growth for second-generation Mexicans (relative to either third-generation Mexicans or U.S.-born whites), rather than because of strong wage growth for Mexican immigrants (see the top panel of Figure 1). The relative wages of Mexicans at age 60 are estimated very imprecisely, however, so from these results we cannot draw firm conclusions about what happens at the end of the working life.

Because the low levels of human capital possessed by Mexican-origin workers account for most of their wage deficit relative to white workers, the predicted wage differentials for Mexicans reported in Table 7 shrink in the regression specification that controls for education and English proficiency. For similar reasons, wage differentials between Mexican immigrants and U.S.-born Mexican Americans also narrow in the extended specification. Moreover, wage deficits between Mexican immigrants and either U.S.-born Mexicans or U.S.-born whites widen over the life cycle once education and especially English proficiency are included in the regression (see the bottom panel of Figure 1). This reinforces the inference drawn earlier from Table 5 that a major component of immigrant assimilation in the U.S. labor market involves English language acquisition.

assumptions do not affect the shapes of the wage profiles or the relative locations of the wage profiles for different ethnicity/generation groups. 


\section{Conclusion}

Using unique Current Population Survey data from November 1979 and 1989, this paper has compared the wage structure across generations of Mexican-origin men. I find that the sizable earnings advantage U.S.-born Mexican Americans enjoy over Mexican immigrants arises not just from intergenerational improvements in years of schooling and English proficiency, but also from increased returns to human capital for Mexican-origin workers who were born and educated in the United States. Even if we consider immigrants who have worked in the United States for 40 years and who therefore have had ample time for labor market assimilation, my estimates indicate that a discrete jump in earnings and the wage structure occurs between the first and second generations. Interestingly, these intergene rational changes in the wage structure take longer to play out for Mexicans than for non-Hispanic whites. The returns to experience are similar for U.S.-born workers regardless of ethnicity (Mexican or white) and generation (second or third and higher), and the returns to education for U.S.-born whites do not vary across generations, but the Mexican returns to education rise for each successive generation, and not until the third generation do they approach the returns of U.S.-born whites. 


\section{References}

Allensworth, Elaine M. 'Earnings Mobility of First and '1.5' Generation Mexican-Origin Women and Men: A Comparison with U.S.-Born Mexican Americans and NonHispanic Whites." International Migration Review, Summer 1997, 31(2), pp. 386410.

Borjas, George J. "Assimilation, Changes in Cohort Quality, and the Earnings of Immigrants." Journal of Labor Economics, October 1985, 3(4), pp. 463-89.

. "Immigrant and Emigrant Earnings: A Longitudinal Study." Economic Inquiry, January 1989, 27(1), pp. 21-37.

. "The Intergenerational Mobility of Immigrants." Journal of Labor Economics, January 1993, Part 1, 11(1), pp. 113-35.

. "Immigrant Skills and Ethnic Spillovers." Journal of Population Economics, 1994, 7(2), pp. 99-118.

- "Assimilation and Changes in Cohort Quality Revisited: What Happened to Immigrant Earnings in the 1980s?" Journal of Labor Economics, April 1995, 13(2), pp. 20145 .

Bratsberg, Bernt, and Terrell, Dek. "School Quality and Returns to Education of U.S. Immigrants.” Manuscript. Manhattan, KS: Kansas State University, 1997.

Carliner, Geoffrey. "The Wages and Language Skills of U.S. Immigrants." Working Paper 5763. Cambridge, MA: NBER, 1996.

Carlson, Leonard A., and Swartz, Caroline. "The Earnings of Women and Ethnic Minorities, 1959-1979." Industrial and Labor Relations Review, July 1988, 41(4), pp. 530-46.

Carnoy, Martin; Daley, Hugh M.; and Hinojosa-Ojeda, Raul. "The Changing Economic Position of Latinos in the U.S. Labor Market Since 1939," in Rebecca Morales and Frank Bonilla, eds., Latinos in a Changing U.S. Economy: Comparative Perspectives on Growing Inequality. Newbury, CA: Sage Publication, 1993, pp. 28-54.

Chapa, Jorge. "The Myth of Hispanic Progress: Trends in the Educational and Economic Attainment of Mexican Americans." Journal of Hispanic Policy, 1990, 4, pp. 3-18.

Chavez, Linda. Out of the Barrio: Toward a New Politics of Hispanic Assimilation. New 
York: Basic Books, 1991.

Chiswick, Barry R. "The Effect of Americanization on the Earnings of Foreign-Born Men." Journal of Political Economy, October 1978, 86(5), pp. 897-921.

. "Sons of Immigrants: Are They at an Earnings Disadvantage?" American Economic Review, February 1977, 67(1), pp. 376-80.

Davila, Alberto; Bohara, Alok K.; and Saenz, Rogelio. "Accent Penalties and the Earnings of Mexican Americans.” Social Science Quarterly, December 1993, 74(4), pp. 902-16.

Duleep, Harriet Orcutt, and Regets, Mark C. "The Elusive Concept of Immigrant Quality: Evidence from 1970-1990." Working Paper PRIP-UI-41. Washington, DC: Urban Institute, 1996.

Friedberg, Rachel M. "The Labor Market Assimilation of Immigrants in the United States: The Role of Age at Arrival." Manuscript. Boston, MA: Massachusetts Institute of Technology, 1991.

Funkhouser, Edward. "How Much of Immigrant Wage Assimilation is Related to English Language Acquisition?" Manuscript. Santa Barbara, CA: University of California, 1996.

Gwartney, James D., and Long, James E. "The Relative Earnings of Blacks and Other Minorities." Industrial and Labor Relations Review, April 1978, 31(3), pp. 336-46.

$\mathrm{Hu}$, Wei-Yin. "Assimilation and the Earnings of Immigrants: New Evidence from Longitudinal Data." Manuscript. Los Angeles: University of California, 1999.

Jasso, Guillermina, and Rosenzweig, Mark R. "How Well Do U.S. Immigrants Do? Vintage Effects, Emigration Selectivity, and Occupational Mobility." Research in Population Economics, 1988, 6, pp. 229-53.

Juhn, Chinhui; Murphy, Kevin M.; and Pierce, Brooks. "Wage Inequality and the Rise in Returns to Skill.” Journal of Political Economy, June 1993, 101(3), pp. 410-42.

Kossoudji, Sherrie A. "Immigrant Worker Assimilation: Is It a Labor Market Phenomenon?" Journal of Human Resources, Summer 1989, 24(3), pp. 494-527.

LaLonde, Robert J., and Topel, Robert H. "The Assimilation of Immigrants in the U.S. Labor Market," in George J. Borjas and Richard B. Freeman, eds., Immigration and the Work Force: Economic Consequences for the United States and Source Areas. Chicago: University of Chicago Press, 1992, pp. 67-92. 
Levy, Frank, and Murnane, Richard J. "U.S. Earnings Levels and Earnings Inequality: A Review of Recent Trends and Proposed Explanations." Journal of Economic Literature, September 1992, 30(3), pp. 1333-81.

Lubotsky, Darren. "Chutes or Ladders? A Longitudinal Analysis of Immigrant Earnings." Working Paper 445. Princeton, NJ: Princeton University Industrial Relations Section, 2000 .

Massey, Douglas S.; Alarcon, Rafael; Durand, Jorge; and Gonzalez, Humberto. Return to Aztlan: The Social Process of International Migration from Western Mexico. Berkeley, CA: University of California Press, 1987.

Murphy, Kevin M., and Welch, Finis. "The Structure of Wages." Quarterly Journal of Economics, February 1992, 107(1), pp. 285-326.

Neidert, Lisa J., and Farley, Reynolds. "Assimilation in the United States: An Analysis of Ethnic and Generation Differences in Status and Achievement." American Sociological Review, December 1985, 50(6), pp. 840-50.

Perlmann, Joel, and Waldinger, Roger. "Second Generation Decline? Children of Immigrants, Past and Present-A Reconsideration." International Migration Review, Winter 1997, 31(4), pp. 893-922.

Ream, Robert K., and Rumberger, Russell W. "On the Move: The Impact of Mobility on the Achievement of Mexican-American and European-American Students." Manuscript. Santa Barbara, CA: University of California, 1998.

Reimers, Cordelia W. "Labor Market Discrimination Against Hispanic and Black Men." Review of Economics and Statistics, November 1983, 65(4), pp. 570-79.

. "The Progress of Mexican and Non-Hispanic White Immigrants in California and Texas, 1980 to 1990." Quarterly Review of Economics and Finance, 1997, 37(Special Issue), pp. 315-43.

Reyes, Belinda I. Dynamics of Immigration: Return Migration to Western Mexico. San Francisco: Public Policy Institute of California, 1997.

Schoeni, Robert F. "New Evidence on the Economic Progress of Foreign-Born Men in the 1970s and 1980s." Journal of Human Resources, Fall 1997, 32(4), pp. 683-740.

Smith, James P. "Hispanics and the American Dream: An Analysis of Hispanic Male Labor Market Wages 1940-1980." Manuscript. Santa Monica, CA: Rand Corporation, 
1991.

Trejo, Stephen J. "Obstacles to the Labor Market Progress of California's Mexican-Origin Workers." Working Paper, vol. 4, no. 1. Berkeley, CA: University of California, Chicano/Latino Policy Project, July 1996.

. "Why Do Mexican Americans Earn Low Wages?" Journal of Political Economy, December 1997, 105(6), pp. 1235-68.

Waters, Mary C. Ethnic Options: Choosing Identities in America. Berkeley, CA: University of California Press, 1990. 
Table 1

Means of Key Variables, by Ethnicity, Generation, and Survey Year

\begin{tabular}{|c|c|c|c|c|c|c|c|c|}
\hline \multirow[b]{2}{*}{ Variable } & \multicolumn{4}{|c|}{ Mexicans, by Generation } & \multicolumn{4}{|c|}{ Whites, by Generation } \\
\hline & All & First & Second & Third & All & First & Second & Third \\
\hline & \multicolumn{8}{|c|}{1979} \\
\hline Log Hourly Earnings & $\begin{array}{l}2.215 \\
(.017)\end{array}$ & $\begin{array}{c}2.000 \\
(.029)\end{array}$ & $\begin{array}{l}2.321 \\
(.032)\end{array}$ & $\begin{array}{l}2.291 \\
(.026)\end{array}$ & $\begin{array}{l}2.459 \\
(.003)\end{array}$ & $\begin{array}{l}2.558 \\
(.024)\end{array}$ & $\begin{array}{l}2.576 \\
(.010)\end{array}$ & $\begin{array}{l}2.442 \\
(.004)\end{array}$ \\
\hline Experience & $\begin{array}{r}17.24 \\
(.43)\end{array}$ & $\begin{array}{c}19.77 \\
(.71)\end{array}$ & $\begin{array}{r}20.29 \\
(.93)\end{array}$ & $\begin{array}{c}13.76 \\
(.60)\end{array}$ & $\begin{array}{r}17.60 \\
(.09)\end{array}$ & $\begin{array}{c}26.13 \\
(.59)\end{array}$ & $\begin{array}{c}24.88 \\
(.27)\end{array}$ & $\begin{array}{r}16.50 \\
(.09)\end{array}$ \\
\hline Speaks English Very Well & $\begin{array}{c}.596 \\
(.018)\end{array}$ & $\begin{array}{c}.098 \\
(.021)\end{array}$ & $\begin{array}{l}.730 \\
(.032)\end{array}$ & $\begin{array}{c}.837 \\
(.020)\end{array}$ & $\begin{array}{c}.990 \\
(.0007)\end{array}$ & $\begin{array}{l}.577 \\
(.024)\end{array}$ & $\begin{array}{c}.993 \\
(.002)\end{array}$ & $\begin{array}{c}.999 \\
(.0002)\end{array}$ \\
\hline Years in U.S. & & $\begin{array}{l}8.52 \\
(.53)\end{array}$ & & & & $\begin{array}{c}15.78 \\
(.52)\end{array}$ & & \\
\hline \multirow[t]{2}{*}{ Sample Size } & 717 & 193 & 194 & 330 & 21,440 & 412 & 2,282 & 18,746 \\
\hline & \multicolumn{8}{|c|}{1989} \\
\hline Experience & $\begin{array}{r}16.56 \\
(.38)\end{array}$ & $\begin{array}{c}19.49 \\
(.62)\end{array}$ & $\begin{array}{r}16.04 \\
(.83)\end{array}$ & $\begin{array}{c}14.29 \\
(.54)\end{array}$ & $\begin{array}{c}17.38 \\
(.08)\end{array}$ & $\begin{array}{r}24.76 \\
(.64)\end{array}$ & $\begin{array}{c}21.83 \\
(.35)\end{array}$ & $\begin{array}{r}16.93 \\
(.08)\end{array}$ \\
\hline Education & $\begin{array}{r}10.43 \\
(.13)\end{array}$ & $\begin{array}{l}7.72 \\
(.24)\end{array}$ & $\begin{array}{r}11.88 \\
(.21)\end{array}$ & $\begin{array}{c}11.97 \\
(.12)\end{array}$ & $\begin{array}{r}13.40 \\
(.02)\end{array}$ & $\begin{array}{r}13.43 \\
(.21)\end{array}$ & $\begin{array}{r}13.75 \\
(.07)\end{array}$ & $\begin{array}{r}13.37 \\
(.02)\end{array}$ \\
\hline Speaks English Very Well & $\begin{array}{c}.623 \\
(.017)\end{array}$ & $\begin{array}{l}.128 \\
(.020)\end{array}$ & $\begin{array}{l}.870 \\
(.025)\end{array}$ & $\begin{array}{c}.914 \\
(.015)\end{array}$ & $\begin{array}{l}.994 \\
(.0006)\end{array}$ & $\begin{array}{l}.678 \\
(.026)\end{array}$ & $\begin{array}{c}.995 \\
(.002)\end{array}$ & $\begin{array}{l}.999 \\
(.0002)\end{array}$ \\
\hline Years in U.S. & & $\begin{array}{c}10.81 \\
(.48)\end{array}$ & & & & $\begin{array}{c}15.56 \\
(.60)\end{array}$ & & \\
\hline Sample Size & 808 & 277 & 189 & 342 & 20,579 & 331 & 1,400 & 18,848 \\
\hline
\end{tabular}

Note: Standard errors are in parentheses. Data are from the November 1979 and November 1989 CPS tapes. The sample includes male wage and salary workers aged 18-61 for whom earnings data are available. Excluded are any immigrants who may have been younger than age 16 when they first arrived in the United States. Hourly earnings are computed as the ratio of usual weekly earnings to usual weekly hours of work. The 1979 earnings data are reported in 1989 dollars to make them comparable with the 1989 earnings data. In tabulating English language proficiency, those who speak only English are presumed to speak English "very well”. Sampling weights were used in the calculations. 
Table 2

Restrictions Imposed on Wage Equations

\begin{tabular}{|c|c|c|c|}
\hline \multirow[b]{2}{*}{ Regressor } & \multicolumn{3}{|c|}{ Coefficients Allowed to Vary Across: } \\
\hline & Ethnicity & Generation & Survey Year \\
\hline Immigrant Cohort and Generation Dummies & Yes & Yes* & No \\
\hline Immigrant Years in U.S. Quadratic & Yes & Yes* & No \\
\hline 1989 Survey Year Dummy & Yes & No & Yes \\
\hline Experience Quadratic & Yes & Yes & Yes \\
\hline Education & Yes & Yes & Yes \\
\hline English Proficiency Dummies & Yes & No & Yes \\
\hline Survey Month Dummies & No & No & Yes \\
\hline Geographic Dummies & No & No & Yes \\
\hline
\end{tabular}

* By construction, the variables indicating the arrival cohort and years of U.S. residence for immigrants do not apply to U.S.-born (i.e., second- and third-generation) workers. 
Table 3

Returns to Education and Experience

\begin{tabular}{|c|c|c|c|c|c|c|}
\hline \multirow[b]{2}{*}{ Variable } & \multicolumn{3}{|c|}{ Mexicans, by Generation } & \multicolumn{3}{|c|}{ Whites, by Generation } \\
\hline & First & Second & Third & First & Second & Third \\
\hline & & & & & & \\
\hline \multicolumn{7}{|l|}{ Coefficients: } \\
\hline \multirow[t]{2}{*}{ Education } & .010 & .022 & .060 & .024 & .055 & .058 \\
\hline & $(.009)$ & $(.009)$ & $(.008)$ & $(.006)$ & $(.003)$ & $(.001)$ \\
\hline \multirow[t]{2}{*}{ Experience } & .004 & .044 & .039 & .030 & .044 & .046 \\
\hline & $(.013)$ & (.009) & $(.007)$ & $(.008)$ & $(.003)$ & $(.001)$ \\
\hline \multirow[t]{2}{*}{ Experience $^{2} / 100$} & -.017 & -.081 & -.060 & -.053 & -.076 & -.080 \\
\hline & $(.027)$ & $(.021)$ & $(.017)$ & $(.016)$ & $(.006)$ & $(.002)$ \\
\hline \multicolumn{7}{|c|}{ Cumulative Returns to Experience: } \\
\hline \multirow[t]{2}{*}{ Ten Years } & .019 & .363 & .331 & .244 & .360 & .380 \\
\hline & $(.105)$ & $(.067)$ & $(.051)$ & $(.064)$ & $(.021)$ & $(.007)$ \\
\hline \multirow[t]{3}{*}{ Twenty Years } & .004 & .563 & .543 & .380 & .569 & 600 \\
\hline & $(.160)$ & $(.096)$ & $(.073)$ & $(.098)$ & $(.032)$ & $(.010)$ \\
\hline & \multicolumn{6}{|c|}{1989} \\
\hline \multicolumn{7}{|l|}{ Coefficients: } \\
\hline \multirow[t]{2}{*}{ Education } & .026 & .051 & .077 & .057 & .079 & .079 \\
\hline & $(.008)$ & $(.010)$ & $(.009)$ & $(.006)$ & $(.004)$ & $(.001)$ \\
\hline \multirow[t]{2}{*}{ Experience } & .022 & .059 & .054 & .010 & .045 & .053 \\
\hline & $(.011)$ & $(.010)$ & $(.007)$ & $(.090)$ & $(.003)$ & $(.001)$ \\
\hline \multirow[t]{2}{*}{ Experience $^{2} / 100$} & -.026 & -.111 & -.078 & -.003 & -.074 & -.088 \\
\hline & $(.024)$ & $(.024)$ & $(.019)$ & $(.019)$ & $(.008)$ & $(.002)$ \\
\hline \multicolumn{7}{|c|}{ Cumulative Returns to Experience: } \\
\hline \multirow[t]{2}{*}{ Ten Years } & .199 & .477 & .467 & .093 & .380 & .437 \\
\hline & $(.089)$ & $(.073)$ & $(.055)$ & $(.072)$ & $(.027)$ & $(.007)$ \\
\hline \multirow[t]{2}{*}{ Twenty Years } & .345 & .734 & .778 & .180 & .613 & .699 \\
\hline & $(.135)$ & $(.103)$ & $(.076)$ & $(.111)$ & $(.039)$ & $(.011)$ \\
\hline
\end{tabular}

Note: Standard errors are in parentheses. The estimates reported above come from the extended specification that utilizes all of the regressors listed in Table 2, including measures of education and English proficiency. 
Table 4

Returns to English Language Proficiency

\begin{tabular}{|c|c|c|c|c|}
\hline \multirow[b]{2}{*}{ Language Category } & \multicolumn{2}{|c|}{ Mexicans } & \multicolumn{2}{|c|}{ Whites } \\
\hline & 1979 & 1989 & 1979 & 1989 \\
\hline $\begin{array}{l}\text { Speaks Only English } \\
\text { (reference group) }\end{array}$ & & & & \\
\hline Speaks English Very Well & $\begin{array}{l}-.042 \\
(.043)\end{array}$ & $\begin{array}{l}-.087 \\
(.041)\end{array}$ & $\begin{array}{l}-.054 \\
(.018)\end{array}$ & $\begin{array}{l}-.070 \\
(.020)\end{array}$ \\
\hline Speaks English Well & $\begin{array}{l}-.091 \\
(.060)\end{array}$ & $\begin{array}{l}-.173 \\
(.060)\end{array}$ & $\begin{array}{l}-.163 \\
(.045)\end{array}$ & $\begin{array}{l}-.124 \\
(.049)\end{array}$ \\
\hline Speaks English Not Well & $\begin{array}{l}-.170 \\
(.077)\end{array}$ & $\begin{array}{l}-.275 \\
(.075)\end{array}$ & $\begin{array}{l}-.318 \\
(.063)\end{array}$ & $\begin{array}{l}-.271 \\
(.078)\end{array}$ \\
\hline Speaks English Not at All & $\begin{array}{l}-.381 \\
(.096)\end{array}$ & $\begin{array}{l}-.331 \\
(.094)\end{array}$ & $\begin{array}{l}-.218 \\
(.118)\end{array}$ & $\begin{array}{l}-.181 \\
(.142)\end{array}$ \\
\hline
\end{tabular}

Note: Standard errors are in parentheses. The estimates reported above come from the extended specification that utilizes all of the regressors listed in Table 2, including measures of education and English proficiency. 
Table 5

Immigrant Wage Growth Over the Life Cycle

Variable

Coefficients:

Years in U.S.

$(\text { Years in U.S. })^{2} / 100$

Cumulative Returns to Years in U.S.:

Ten Years

Twenty Years
Cumulative U.S. Wage Growth:

Ten Years

Twenty Years

\begin{tabular}{cc}
\multicolumn{2}{c}{ Mexicans } \\
\hline Base & Extended \\
Specification & Specification \\
\hline
\end{tabular}

.044

$(.012)$

$-.090$

(.043)

.349

(.096)

.519

(.165)

.416

$(.084)$

.626

(.149)
.028

$(.012)$

$-.078$

(.041)

.200

(.094)

.243

(.160)

.399

$(.088)$

.589

(.155)

\begin{tabular}{cc}
\multicolumn{2}{c}{ Whites } \\
\hline Base & Extended \\
Specification & Specification \\
\hline
\end{tabular}

.024

.017

(.009)

(.009)

$-.016$

$-.036$

(.020)

$(.021)$

.223

(.077)

.135

(.074)

.414

(.127)

(.123)

.397

.228

(.070)

(.084)

.643

(.112)

Note: Standard errors are in parentheses. Cumulative U.S. wage growth for immigrants is the sum of returns to years in U.S. and returns to experience. The wage growth calculations reported above use 1989 estimates of the returns to experience for immigrants. The base specification includes all of the regressors listed in Table 2 except for education and the English proficiency dummies. The extended specification adds controls for education and English proficiency to the base specification. 
Table 6

Log Wage Differentials Between Immigrant Arrival Cohorts

\begin{tabular}{|c|c|c|c|c|}
\hline \multirow[b]{2}{*}{ Immigrant Cohort } & \multicolumn{2}{|c|}{ Mexicans } & \multicolumn{2}{|c|}{ Whites } \\
\hline & $\begin{array}{c}\text { Base } \\
\text { Specification }\end{array}$ & $\begin{array}{c}\text { Extended } \\
\text { Specification }\end{array}$ & $\begin{array}{c}\text { Base } \\
\text { Specification }\end{array}$ & $\begin{array}{c}\text { Extended } \\
\text { Specification } \\
\end{array}$ \\
\hline $\begin{array}{l}\text { Pre-1960 Arrivals } \\
\text { (reference group) }\end{array}$ & & & & \\
\hline 1960-69 Arrivals & $\begin{array}{l}-.292 \\
(.220)\end{array}$ & $\begin{array}{l}-.317 \\
(.209)\end{array}$ & $\begin{array}{l}.037 \\
(.087)\end{array}$ & $\begin{array}{l}.0002 \\
(.081)\end{array}$ \\
\hline 1970-79 Arrivals & $\begin{array}{l}-.319 \\
(.275)\end{array}$ & $\begin{array}{l}-.390 \\
(.261)\end{array}$ & $\begin{array}{c}.083 \\
(.128)\end{array}$ & $\begin{array}{c}.063 \\
(.119)\end{array}$ \\
\hline 1980-89 Arrivals & $\begin{array}{l}-.282 \\
(.323)\end{array}$ & $\begin{array}{l}-.376 \\
(.308)\end{array}$ & $\begin{array}{c}.185 \\
(.173)\end{array}$ & $\begin{array}{c}.080 \\
(.168)\end{array}$ \\
\hline
\end{tabular}

Note: Standard errors are in parentheses. The base specification includes all of the regressors listed in Table 2 except for education and the English proficiency dummies. The extended specification adds controls for education and English proficiency to the base specification. 
Table 7

Predicted Log Wage Differentials at Three Points in the Life Cycle

(Relative to Third-Generation Whites)

\begin{tabular}{|c|c|c|c|c|c|c|}
\hline \multirow[b]{2}{*}{ Specification/Generation } & \multicolumn{3}{|c|}{ Mexicans } & \multicolumn{3}{|c|}{ Whites } \\
\hline & Age 20 & Age 40 & Age 60 & Age 20 & Age 40 & Age 60 \\
\hline \multicolumn{7}{|l|}{ Base Specification: } \\
\hline \multirow[t]{2}{*}{ First Generation } & -.551 & -.590 & -.525 & .175 & .115 & .375 \\
\hline & $(.073)$ & $(.114)$ & $(.432)$ & $(.066)$ & $(.090)$ & $(.201)$ \\
\hline \multirow[t]{2}{*}{ Second Generation } & -.245 & -.199 & -.405 & .054 & .061 & .057 \\
\hline & $(.055)$ & $(.051)$ & $(.119)$ & $(.020)$ & $(.018)$ & $(.031)$ \\
\hline \multirow[t]{2}{*}{ Third Generation } & -.235 & -.262 & -.108 & & reference & \\
\hline & $(.045)$ & $(.038)$ & $(.116)$ & & group & \\
\hline \multicolumn{7}{|l|}{ Extended Specification: } \\
\hline \multirow[t]{2}{*}{ First Generation } & -.136 & -.196 & -.387 & .306 & .056 & .204 \\
\hline & $(.096)$ & $(.122)$ & $(.409)$ & $(.070)$ & $(.100)$ & (.193) \\
\hline \multirow[t]{2}{*}{ Second Generation } & .0002 & .017 & -.146 & .077 & .002 & .041 \\
\hline & $(.070)$ & $(.056)$ & $(.126)$ & $(.025)$ & $(.020)$ & $(.029)$ \\
\hline \multirow[t]{2}{*}{ Third Generation } & -.109 & -.022 & .147 & & reference & \\
\hline & $(.049)$ & $(.043)$ & $(.116)$ & & group & \\
\hline
\end{tabular}

Note: Standard errors are in parentheses. The base specification includes all of the regressors listed in Table 2 except for education and the English proficiency dummies. The extended specification adds controls for education and English proficiency to the base specification. The calculations reported above use estimated coefficients for 1989 and refer to an individual with 12 years of schooling who speaks only English and entered the labor market at age 18. If an immigrant (i.e., first generation), the individual is assumed to have arrived in the United States at age 20 as part of the 1980-89 cohort. 


\section{Figure 1}

Estimated Wage Profiles for Mexicans and Third-Generation Whites

\section{A. Base Specification}

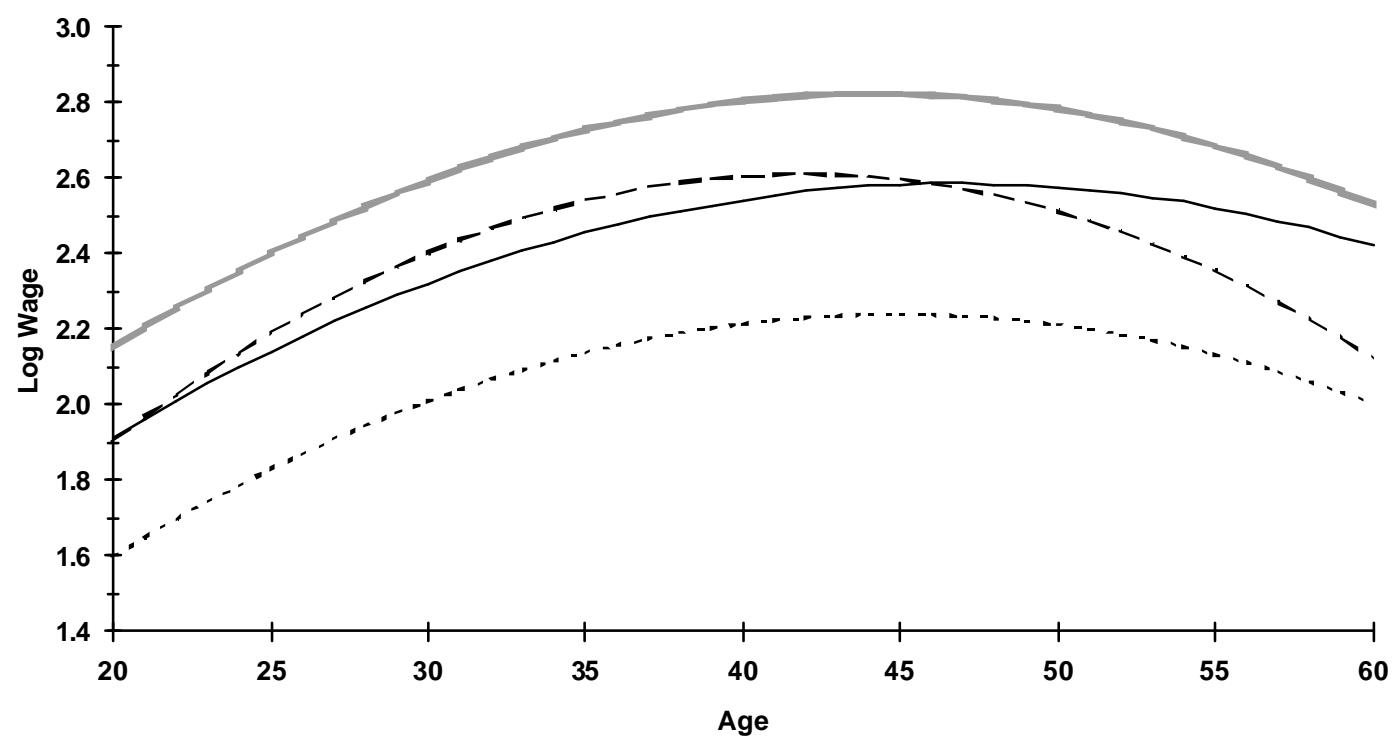

B. Extended Specification

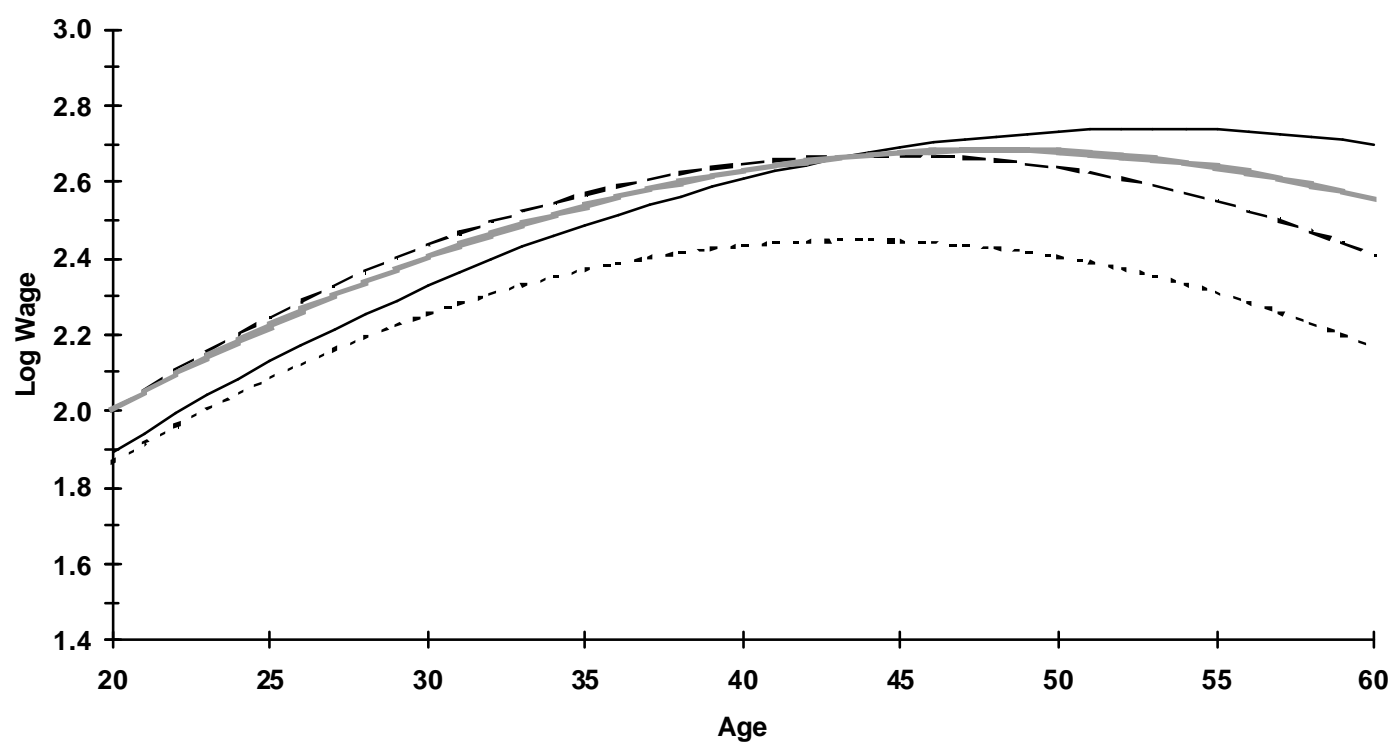

\begin{tabular}{|ll|}
\hline$\cdots-1$ 1st Gen. Mexicans & --- 2nd Gen. Mexicans \\
- 3rd Gen. Mexicans & 3rd Gen. Whites \\
\hline
\end{tabular}




\section{IZA Discussion Papers}

\begin{tabular}{|c|c|c|c|c|}
\hline No. & Author(s) & Title & Area & Date \\
\hline 363 & $\begin{array}{l}\text { H. Antecol } \\
\text { D. A. Cobb-Clark } \\
\text { S. J. Trejo }\end{array}$ & $\begin{array}{l}\text { Immigration Policy and the Skills of Immigrants } \\
\text { to Australia, Canada, and the United States }\end{array}$ & 2 & $09 / 01$ \\
\hline 364 & $\begin{array}{l}\text { M. Jäntti } \\
\text { S. P. Jenkins }\end{array}$ & $\begin{array}{l}\text { Examining the Impact of Macro-Economic } \\
\text { Conditions on Income Inequality }\end{array}$ & 3 & $09 / 01$ \\
\hline 365 & $\begin{array}{l}\text { H. S. Nielsen } \\
\text { M. Rosholm } \\
\text { N. Smith } \\
\text { L. Husted }\end{array}$ & $\begin{array}{l}\text { Qualifications, Discrimination, or Assimilation? } \\
\text { An Extended Framework for Analysing } \\
\text { Immigrant Wage Gaps }\end{array}$ & 1 & $09 / 01$ \\
\hline 366 & M. C. Regets & $\begin{array}{l}\text { Research and Policy Issues in High-Skilled } \\
\text { International Migration: A Perspective with Data } \\
\text { from the United States }\end{array}$ & $1 / 5$ & $09 / 01$ \\
\hline 367 & C. Dustmann & $\begin{array}{l}\text { Parental Background, Primary to Secondary } \\
\text { School Transitions, and Wages }\end{array}$ & 5 & $09 / 01$ \\
\hline 368 & J. Angrist & $\begin{array}{l}\text { How Do Sex Ratios Affect Marriage and Labor } \\
\text { Markets? Evidence from America's Second } \\
\text { Generation }\end{array}$ & 5 & $09 / 01$ \\
\hline 369 & A. S. Kalwij & $\begin{array}{l}\text { Individuals' Unemployment Durations over the } \\
\text { Business Cycle }\end{array}$ & 3 & $09 / 01$ \\
\hline 370 & A. S. Kalwij & $\begin{array}{l}\text { Individuals' Unemployment Experiences: } \\
\text { Heterogeneity and Business Cycle Effects }\end{array}$ & 3 & $09 / 01$ \\
\hline 371 & $\begin{array}{l}\text { S. C. Wolter } \\
\text { A. Zbinden }\end{array}$ & $\begin{array}{l}\text { Rates of Return to Education: The View of } \\
\text { Students in Switzerland }\end{array}$ & 5 & $09 / 01$ \\
\hline 372 & $\begin{array}{l}\text { J. Konings } \\
\text { H. Lehmann }\end{array}$ & $\begin{array}{l}\text { Marshall and Labour Demand in Russia: Going } \\
\text { Back to Basics }\end{array}$ & 4 & $09 / 01$ \\
\hline 373 & S. J. Trejo & $\begin{array}{l}\text { Does the Statutory Overtime Premium } \\
\text { Discourage Long Workweeks? }\end{array}$ & 1 & $10 / 01$ \\
\hline 374 & $\begin{array}{l}\text { G. J. van den Berg } \\
\text { B. van der Klaauw }\end{array}$ & $\begin{array}{l}\text { Counseling and Monitoring of Unemployed } \\
\text { Workers: Theory and Evidence from a } \\
\text { Controlled Social Experiment }\end{array}$ & 6 & $10 / 01$ \\
\hline 375 & $\begin{array}{l}\text { J. A. Dunlevy } \\
\text { W. K. Hutchinson }\end{array}$ & $\begin{array}{l}\text { The Pro-Trade Effect of Immigration on } \\
\text { American Exports During the Late Nineteenth } \\
\text { and Early Twentieth Centuries }\end{array}$ & 1 & $10 / 01$ \\
\hline 376 & G. Corneo & Work and Television & 5 & $10 / 01$ \\
\hline 377 & S. J. Trejo & $\begin{array}{l}\text { Intergenerational Progress of Mexican-Origin } \\
\text { Workers in the U.S. Labor Market }\end{array}$ & 1 & $10 / 01$ \\
\hline
\end{tabular}

